\title{
Are perception and adaptation to climate variability and change of cowpea growers in Mali gender differentiated?
}

\author{
Fatimata Bintou Diarra' ${ }^{1,2} \cdot$ Mathieu Ouédraogo ${ }^{1}$ (D . Robert B. Zougmoré ${ }^{\text {. }}$ \\ Samuel Tetteh Partey ${ }^{1} \cdot$ Prosper Houessionon ${ }^{1} \cdot$ Amos Mensah $^{2}$
}

Received: 12 March 2019 / Accepted: 14 January 2021 / Published online: 27 January 2021

(C) The Author(s) 2021

\begin{abstract}
Understanding the gender dimension of climate change perception and choice of adaptation strategies is crucial for policy recommendations that foster the development and integration of gender-responsive climate-smart agricultural interventions into agricultural development programs. This study determined the differences in the perception and choice of adaptation strategies between men and women farmers in Cinzana in the Segou region of Mali. The study used questionnaire interviews involving 260 farmers (49\% women) and focus group discussions for data collection. Data were analyzed using descriptive statistics and multinomial logit model to understand the determinants of the level of adoption of adaptation strategies. The results showed that, irrespective of gender, majority of farmers perceived climate change as extended period of droughts, shortened duration of rains, increased frequency of strong winds and increased day and night temperatures. While climate change perception was similar between men and women, choice of adaptation strategies differed significantly in most instances. Women farmers were generally low adopters of crop and varieties-related strategies, soil and water conservation technics (contour farming, use of organic manure), etc., compare to men. Notably, being the household head, age and the availability of free labor were found to positively increased farmers' probability of adopting many adaptation strategies. The study recommends improving women's access and control of production resources (land, labor) as means to improving their adoption of adaptation strategies.
\end{abstract}

Keywords Gender $\cdot$ Climate change $\cdot$ Perception $\cdot$ Adaptation $\cdot$ Mali

\section{Introduction}

Climate change is a global problem; it affects people all over the world in varying intensities (IPCC 2018). Developing countries, more specifically in West Africa, are more sensitive and at risk of climate change manifestations due to the over reliance of more

Mathieu Ouédraogo

m.ouedraogo@cgiar.org

Extended author information available on the last page of the article 
than $90 \%$ of agricultural production systems on rainfall with limited adaptive capacities (Müller et al. 2011; Jalloh et al. 2013). This challenges efforts to improve food security and alleviate poverty at levels set in the United Nation agenda 2030 sustainable development goals (Barnett et al. 2008a, b; Barrett 2010; UN 2017). Like most of Sub-Saharan Africa (SSA) countries, the variability of precipitation associated with droughts has been identified as the most important cause of famines and food shortages in Mali (Haile 2005; Zougmoré et al. 2018). Predictive models project food insecurity in Mali could increase from 64 to $72 \%$ of the Malian population by 2030 owing to adverse climate change effects (Butt et al. 2004). This has been attributed to the reduction trend in cereal production projected to decrease by 15 to $19 \%$ by 2030 . In addition, prices of food items are expected to double as a result of climate change (Butt et al. 2004; Aune 2008; IPCC 2014). With growing climate uncertainties, the need for adaptation planning is timely but will begin from a better understanding of local farmers' perception and adaptation strategies (Ofuoku 2011; Mitter et al. 2019). This is crucial for policy recommendations that foster the development and integration of sustainable climatesmart agricultural interventions into rural development planning programs.

The theoretical context of climate change perception is built on observation, personal experience and information received from the surroundings/neighborhood over a period of time. Evidence suggests that the perceptive process by which individuals receive information or stimuli from the environment and transform it into psychological awareness influence their decision to undertake required measures (Bridgeman and Tseng 2011). In the context of climate change, an individual's decision to adopt adaptive measures has been shown to be defined by their experiential knowledge of weather patterns (mainly changes in temperature and rainfall) and extreme events (e.g., drought, strong winds, floods, etc.) over a period of time (Swai et al. 2012; Partey et al. 2018). Adaptation is, however, seen as the most basic way by which one can respond to the adverse impact of climate change (Davis et al. 2009). It is how individuals, groups and natural systems make preparations for and react to perceived changes in climate (Bryant et al. 2000).

Although it is assumed that every individual will be affected by climate change, climate experts and literature suggest that women in SSA are more vulnerable and worse affected by climate change (Bravo-Baumann 2000). This is due to statutory and/or customary laws that often restrict women's property and land rights and their limited access to important resources (land, extension services, information and credit, etc.) that further undermine their adaptive capacity (Swai et al. 2012). This is no different from Mali where gendered social norms and roles inhibit women's adaptive capacity (Nelson and Stathers 2009; Peterman et al. 2010; Doss 2011; FAO 2011; Kakota et al. 2011; Wright and Chandani 2014; and Jost et al. 2015). It has been estimated that if women in rural areas are given equal access to agricultural resources, yields could increase by 20 to $30 \%$ and the total number of hungry people in the world could be reduced by 12 to $17 \%$ (FAO 2011). It is therefore imperative that gendered differentiated information on climate change adaptation is known as a means to developing gender-response adaptation strategies to climate change. In Mali, the effects of climate change on livelihood activities have received much attention with limited information on the gender dimension of climate change perception and choice of adaptation strategies (e.g., Touré et al. 2016; Diiro et al. 2016; Sanogo et al. 2016; Traore et al. 2017a, b). For instance, studies by Touré et al. (2016) and Diiro et al. (2016) provide an overview of climate change implications for the agricultural sector of Mali and the call to adopt innovative and sustainable solutions to avert climate-related risks. However, there is no reference to gender differentiate information to accentuate implications on 
the development of agricultural development plans and policies as part of local adaptation planning actions.

This study is therefore timely and aimed to use sex-disaggregated data to (i) understand how women and men farmers perceive climate change, (ii) analyze women and men farmers' adaptation strategies to climate change and (iii) identify the key determinants of the level of adoption of adaptation strategies. The research sought to generate relevant data and information to help policymakers and development practitioners to mainstream gender in their development initiatives.

\section{Methodology}

\subsection{Study area}

The study was conducted in the Segou region of Mali, within the climate-smart village (CSV) site of Cinzana established by the CGIAR Research Program on Climate Change, Agriculture and Food Security (CCAFS). The CSV site of Cinzana is a rectangular block of land measuring approximately 30 by $30 \mathrm{~km}$ covering 48 villages. Cinzana belongs to the Sahelian agro ecological zone of Mali. It is located between $13^{\circ} 53^{\prime} \mathrm{N}$ and $13^{\circ} 14^{\prime} \mathrm{N}$ latitude and $5^{\circ} 63^{\prime} \mathrm{W}-6^{\circ} 15^{\prime} \mathrm{W}$ longitude (https://ccafs.cgiar.org/mali). Rainfall is unimodal with the maximum rain events occurring in July and August. Average annual rainfall is about $680 \mathrm{~mm}$. The rainy season lasts from May to October. Low temperatures occur in December through February $\left(18{ }^{\circ} \mathrm{C}\right.$ monthly average low), and high temperatures occur in April and May ( $40^{\circ} \mathrm{C}$ monthly average high) (Traore et al. 2017a, b).

Millet and sorghum are the most staple cereals produced in the study area, while groundnut, cowpea and sesame are cultivated as major cash crops (Ouédraogo et al. 2017). Cereals are grown by more men than women, groundnut by more women. Cowpea is produced by as many women as men. Women are more active in gardening activities, processing of agricultural product and breeding of small ruminants. As in Mali, women farmers from Segou region have a limited access and control of the resources needed to increase productivity (i.e., land and equipment). In Mali, land is inherited paternally (father to son) or allocated by the chief of the village in rural area (Doss et al. 2014). Women have access to family land only through the man head of the household. They do not own it. Their land size is relatively small with more than $54 \%$ of women having less than 1 hectare of land in Mali. Only 6\% of women have more than 5 ha against 32\% for men (MA 2016). Women can use family land for their crops. They can make agriculture decision about their own production but they use the resulting income to support their husband activities. They have authority over only their home garden and the income from them.

The study was carried out in eight villages-Folanassibougou, N'Tlomabougou, Tongo, Siekourani, Kamanago, Dougakoungo, N'Gakoro and Kallan located in Cinzana. The study villages have been selected based on the distances from each other to make the data more representative of the entire commune of Cinzana (CCAFS 2011).

\subsection{Data collection and analysis}

Given that the study was interested in the differences in perception and adaptation strategies between women and men farmers, data were collected from individual cowpea farmers to ensure that women farmers are interviewed and that their voices are considered. 
Considering the fact that few households are headed by women in Mali because of the culture in the country (Touré et al. 2016), it was necessary for the study to target individual farmers in order to have the chance to interview women and men farmers and reach the study objectives. Cowpea farmers were targeted in this study because cowpea is grown by both men and women in Mali unlike other crops such as pearl millet, sorghum and maize noted as men's crops, while groundnut is categorized as women's crop.

The geographical characteristics of the eight villages informed the choice of multistage sampling. The first stage purposively sampled the study villages based on where cowpea is predominantly produced in the CSV. Farmers were then categorized into women and men groups. Third, a simple non-random sampling was adopted to select the respondents for the study. To ensure data reliability with regard to climate change perception, the study selected respondents who have been resident in the community for at least ten years prior to the study. Given that climate change is longer-term trend (different from natural weather variability), the study assumed that its perception by farmers will be affected by age (Ouédraogo et al. 2010; Alle et al. 2013). Thus, to really appreciate its perception by farmer in a given location, we should consider a minimum residence time in this location.

Survey questionnaires and interview guides were used for the primary data collection. The study was conducted with two hundred and sixty (260) farmers comprising one hundred and twenty-seven (127) women and one hundred and thirty-three (133) men. Some men and women farmers belong to the same household and some not. Equally, interviews and focus group discussions were led by men or women according to the sex of the respondents in order to allow them to be comfortable.

Data from focus group discussions were suited for the purposes of triangulation with the survey data. Two focus groups (one with women and one with men) were conducted in each village giving a total of sixteen group discussions. The focus group discussions provided useful information for the finalization of the questionnaires for the individual survey. Data were analyzed using descriptive statistics and econometric modeling based on the multinomial logit. Descriptive statistics were used to analyze farmers' perception of changes in climate. A Pearson $\mathrm{chi}^{2}$ was used to determine the existence of differences between men's and women's adaptation levels. A multinomial logit model was used to understand, predict and identify the various factors which affect women and men adoption levels of adaptation strategies.

\subsection{Analytical and theoretical framework}

The multinomial logit model (MNL) represents an appropriate framework to explore and explain choice processes where the choice set consists of more than two alternatives (Greene 1998). The advantage of using a MNL model is its computational simplicity in calculating the choice probabilities that are expressible in analytical form (Tse 1987). The model also provides a convenient closed form for underlying choice probabilities, with no need of multivariate integration, making it simple to compute choice situations characterized by many alternatives (Hausman and McFadden 1984). It was highlighted by Touré et al. (2016) and confirmed by the current survey that farmers in the Cinzana area combine different agriculture coping strategies. Therefore, to analyze the farmers' adaptation strategies, it was necessary to categorize them into several classes based on the number of adaptations strategies adopted. This study adopted the CCAFS adaptability index (CCAFS 2011) with some changes to categorize farmers according their levels of adaptation. CCAFS adaptability index 
categorizes farmer as low level of adaptability if it has not made any change, intermediate level when it has adopted 1-4 strategies and high level when the household uses more than 5 strategies. Based on this index, this study categorized farmers' levels of adaptation to climate change as follows:

- Low level when farmers are using one (1) to four (4) strategies,

- Medium level for five (5) to height (8) strategies, and

- High level for nine (9) to thirteen (13) strategies.

Suppose that there is $\mathbf{J}$ alternative of adaptation levels, the MNL model is expressed as follows:

$$
\log \left(\frac{P_{i j}}{P_{i 1}}\right)=x_{i} \beta_{j} \quad \text { for } j=1, \ldots, J ; i=1, \ldots, N
$$

where $P_{i j}$ is $\operatorname{Prob}(Y=1 / x)$ which is obtained as follows:

$$
P_{i j}=\frac{\exp \left(x_{i} \beta_{j}\right)}{\sum_{j=1}^{J} \exp \left(x_{i} \beta_{j}\right)}
$$

Equation (2) can be estimated by the method of maximum likelihood. In this model, the probability is obtained as follows:

$$
P(Y=j)=\frac{\exp \left\{x_{i} \beta_{j}\right\}}{1+\sum_{j=1}^{J} \exp \left\{x_{i} \beta_{j}\right\}}
$$

where for $\mathrm{j}=1,2, \ldots, J ; \mathrm{i}=1,2, \ldots, N$

The parameter estimates for the $J$ vectors that maximize the log likelihood function can be obtained using the Newton method (Greene 1998). Marginal probabilities of choice (marginal effects) can be calculated from Eq. (3) below:

$$
\frac{\partial P_{i y}}{\partial P x_{i}}=P_{i j} \beta_{j}-\sum_{k=1}^{J} P_{i k} \beta_{k o} \quad \text { for } j=1, \ldots, J
$$

Using Eq. (4), we can find changes in probabilities for being in the adoption level 1 due to a slight change in one of the farmers' characteristics, while holding all other explanatory variables fixed.

\subsection{Analytical and theoretical framework}

The dependent variable used for this study is farmers adopted level of adaptation strategies (ADAPT), while the independent or explanatory variables included sex of respondent, literacy, access to extension services, land size, age, labor availability and household head. These variables have been well-thought-out by several previous studies as factors which may influence farmers' adaptation strategies (Aymone 2009; Maddison 2006; Doss 2014; Ouédraogo et al. 2017). 


\subsubsection{Sex of respondent (SEX)}

This is a dummy variable having 1 as a value when the respondent is a man and 0 when the respondent is a woman. The sex of a respondent may influence his/her access to needed information, opportunities to adopt some technologies.

\subsubsection{Literacy}

Literacy is a dummy variable taking 1 when the respondent knows how to read and write either in a local language or in French and taking zero for the contrary. Education may influence a farmer adoption of certain technologies, especially if the technology is complex (following a notice or recommendation, writing planting or specifics dates, etc.). It can also affect a farmer's receptivity to an extension agent (Ouédraogo et al. 2017). As explained by Norris and Batie (1987), a higher level of education may likely increase a person access to information, to extension and influences his/her adoption level.

\subsubsection{Access to extension services}

This refers to the frequent visit of extension officers in the villages of the study area and their level of interaction with men and women farmers. It also refers to the duration of this interaction. As reported by Maddison (2006) and Aymone (2009), access to extension fosters first, farmer's exposure to different adaptation strategies and secondly, raises the likelihood of farmers taking action to cope with climate change effect.

\subsubsection{Land size}

It is a continuous variable measuring the number of hectares used by individual farmers in 2015. Land size is recognized to have an influence on farmers' adaptation decisions and on yield (Bradshaw et al. 2004; Aymone 2009). This impact can be negative or positive depending on the type of strategy.

\subsubsection{Age}

It is a continuous variable; it may positively or negatively influence farmers' adaptation capacity, resources, experience and yield. Nhemachena and Hassan (2008) and Maddison (2006) indicate that age as a proxy for farming experience can influence the probability of applying climate change adaptation measures.

\subsubsection{Labor}

The availability may have positive or negative effect on farmer' level of adoption depending on the type of strategies. For instance, technologies which require a lot of labor may not be adopted by a farmer who does not have access to enough free labor because of the cost of hiring. Shortage of labor has been cited by Ethiopian farmers as one of the major reasons of their inability to adopt most adaptation strategies (Deressa et al. 2009). We therefore expect that farm households with more labor are better able to take up adaptations in response to changes in climate (Nhemachena and Hassan 2008). Even if the possibility for farmers to hire extra labor exists few rural farmers can do so. 


\subsubsection{Household head}

It is also a dummy variable taking one (1) when the respondent is the household head and zero (0) if not. The household head is the decision maker for the entire household. It is assumed that he is the one who decides which strategies the family is going to use. The expected effect of being household head on the adoption level is positive.

The empirical model is given by:

$$
\begin{aligned}
& \text { ADAPT }=\beta_{0}+\beta_{1} \text { Sex }+\beta_{2} \text { Age }+\beta_{3} \text { Hhh }+\beta_{4} \text { number of working children }+ \\
& \beta_{5} \text { Litteracy }+\beta_{6} \text { Accesstoextensionofficers }+X_{7 i} \text { Plotsize }+ \\
& X_{8 i} \text { Landtenure }+\varepsilon_{i}
\end{aligned}
$$

where

- ADAPT represents the level of adoption of strategies $(1=$ low, $2=$ medium and $3=$ high level),

- $\beta_{0}$ is the intercept, and $\beta_{1}, \beta_{2}, \ldots \beta_{k}$ represent the estimated coefficients of explanatory variables.

- $X_{1 i}$ Corresponds to the sex of respondent, $X_{2 i}$ is equal to age of respondent (a proxy for farm experience), $X_{3 i}$ is household head, $X_{4 i}$ represents family labor (number of working children), $X_{5 i}$ indicates the respondent literacy, $X_{6 i}$ is equal to respondent access to extension services, $X_{7 i}$ represents the size of interviewer plot, while $X_{8 i}$ is land tenure and $\varepsilon_{i}$ is error term.

\section{Results and discussion}

\subsection{Farmers sociodemographic characteristics}

Table 1 presents the sociodemographic information of respondents. The result shows that few farmers are literate $(16.5 \%)$ and men are more literate than women. About $15.8 \%$ of women were head of household compared to men who represented $67.7 \%$ of the household heads. About $88.08 \%$ of farmers in the sample are land owner and $66.15 \%$ of them inherited their land.

About $96 \%$ of women and $84.5 \%$ of men were members of farmer-based organization. About $62 \%$ of men farmers were working with extension officers versus $36.22 \%$ of women

Table 1 Sample sociodemographic characteristics (\%)

\begin{tabular}{llll}
\hline Variables & Women $(N=133)$ & Men $(N=127)$ & Total $(s=260)$ \\
\hline Literacy & 11.02 & 21.15 & 16.15 \\
Head of household & 15.75 & 67.67 & 42.31 \\
Land owner & 83.46 & 92.48 & 88.08 \\
Inherited land & 33.86 & 96.99 & 66.15 \\
Farmers' association & 96.06 & 86.47 & 91.15 \\
Extension officer & 36.22 & 61.65 & 49.23 \\
\hline
\end{tabular}


in the sample. During the group discussions, women said was recently that they started working with extension services.

\subsection{Farmer's perception of climate change}

A three Likert scale was used to determine farmer's perception of climate change. Table 2 presents the results of farmers' perception of climate change. It shows that farmers in Cinzana have perceived a lot of changes in their climate and environment. They have perceived some shifts in the beginning and the ending period of the rainy season. In fact, $45 \%$ of the respondents disagrees with the early beginning of the rainy season out of which $40 \%$ are women and $50 \%$ are men. Majority of respondents (62\%) agree with the early ending of rainy season, while totality $(100 \%)$ of the sample disagrees with the late beginning of the dry season. This result is in line with several studies conducted in West Africa. Toure et al. (2016) found that $94.1 \%$ of farmers perceived a decrease in the length of the rainy season witch implicitly means an increase in dry season in Cinzana. Maddison (2006) reported that farmers perceived the change in the beginning and the end of rainy season in seven sub-Saharan African countries including Senegal, Burkina Faso and Niger. Sanogo et al. (2016) reported a decrease in the rainy season from six (6) months to four (4) months in the southern part of Mali.

Farmers in Cinzana perceived a decrease in rain intensity and quantity during the season. Almost $47 \%$ of women and $53 \%$ of men disagree with the increased frequency of rainy days during the season. This confirm the findings from Touré et al. (2016) and Sanogo et al. (2016).

Farmers, in Cinzana area have noticed an increase of daily and night temperatures. Both women and men are perceiving changes in the day and night average temperatures. About $72 \%$ of women and $74 \%$ of men have perceived an increase in the day temperature. Similarly, $65 \%$ of women and $63 \%$ of men disagreed with the decrease in night temperature. This finding is in line with Sanogo et al. (2016) who reported an increase of temperature and number of hot days in southern Mali. However, Touré et al. (2016) reported that few farmers of its study sample perceived a change in temperature in Cinzana area.

Cinzana farmers have also perceived an increase of strong wind frequency. About $61 \%$ of women and $65 \%$ of men disagree with the decreased of strong wind frequency, whereas $56 \%$ of women and $72 \%$ of men have noticed a decrease in spontaneous bushfire. The same phenomenon has been observed in Mopti region (Mali) where $83 \%$ of the respondent had noticed an increase of strong winds (Diiro et al. 2016). Farmers have also found their soil less fertile than the past ten years. About $96 \%$ of the sample reported their soil to be less fertile than 10 years ago, while almost $45 \%$ of women and $54 \%$ of men disagree with the fact that they are experiencing less soil erosion problem. This is in agreement with Toure et al. (2016) and Sanogo et al. (2016) findings.

In general, the study found that women and men farmers have the same perception of climate change in Cinzana area. They equally perceive changes in the rainy season pattern, temperature, soil quality and extreme phenomena. Diiro et al. (2016) and Partey et al. (2018) also reported the similitude of women and men farmers' perceptions of climate in Mopti region and in the Upper West Region of Ghana. Sanogo et al. (2016) contrary reported a significant difference between male and women perception. Male farmers were more likely to notice changes in climate as compared to female farmers in southern Mali (Sanogo et al. 2016). 
Table 2 Farmers' perception of climate change (\%)

\begin{tabular}{|c|c|c|c|c|}
\hline Perception & Sex & Disagree & Neutral & Agree \\
\hline \multicolumn{5}{|l|}{ Perception of rain season pattern } \\
\hline \multirow[t]{3}{*}{ Early beginning of the season } & Women & 39.37 & 25.20 & 35.43 \\
\hline & Men & 50.38 & 6.02 & 43.61 \\
\hline & Pool & 45.00 & 15.38 & 39.62 \\
\hline \multirow[t]{3}{*}{ Early ending of the season } & Women & 17.32 & 29.92 & 52.76 \\
\hline & Men & 18.05 & 11.28 & 70.68 \\
\hline & Pool & 17.69 & 20.38 & 61.92 \\
\hline \multirow[t]{4}{*}{ Increased frequency of rainy days } & Women & 47.24 & 29.92 & 22.83 \\
\hline & Men & 53.38 & 12.78 & 33.83 \\
\hline & Men & 31.58 & 5.26 & 63.66 \\
\hline & Pool & 26.92 & 11.15 & 61.92 \\
\hline \multirow[t]{3}{*}{ Late beginning of dry season } & Women & 100 & 0 & 0 \\
\hline & Men & 100 & 0 & 0 \\
\hline & Pool & 100 & 0 & 0 \\
\hline \multicolumn{5}{|l|}{ Perception of temperature pattern } \\
\hline \multirow[t]{3}{*}{ Increase in day temperature } & Women & 8.66 & 19.69 & 71.65 \\
\hline & Men & 14.29 & 11.28 & 74.44 \\
\hline & Pool & 11.54 & 15.38 & 73.08 \\
\hline \multirow[t]{3}{*}{ Increase in night temperature } & Women & 65.35 & 20.47 & 14.17 \\
\hline & Men & 63.15 & 11.27 & 25.56 \\
\hline & Pool & 64.23 & 15.76 & 20.00 \\
\hline \multicolumn{5}{|c|}{ Perception of extreme phenomena pattern } \\
\hline \multirow[t]{3}{*}{ Decreased frequency of strong wind } & Women & 60.63 & 15.74 & 23.62 \\
\hline & Men & 64.66 & 13.53 & 21.80 \\
\hline & Pool & 62.69 & 14.62 & 22.69 \\
\hline \multirow[t]{3}{*}{ Increased of spontaneous bush fires } & Women & 55.91 & 39.37 & 4.72 \\
\hline & Men & 72.18 & 16.54 & 11.28 \\
\hline & Pool & 64.23 & 7.69 & 8.08 \\
\hline \multicolumn{5}{|l|}{ Soil quality pattern } \\
\hline \multirow[t]{3}{*}{ Improved of soil fertility } & Women & 96.06 & 0.79 & 4.72 \\
\hline & Men & 92.48 & 4.51 & 2.69 \\
\hline & Pool & 96.06 & 4.61 & 3.46 \\
\hline \multirow[t]{3}{*}{ More soil erosion problem } & Women & 44.88 & 27.56 & 27.56 \\
\hline & Men & 54.14 & 25.56 & 20.30 \\
\hline & Pool & 49.61 & 26.54 & 23.85 \\
\hline
\end{tabular}

Number of observations $=260$

\subsection{On-farm climate change adaptation strategies}

The study showed that farmers have adopted different adaptation strategies to face climate change manifestations over the past ten years (Table 3). These strategies were divided into four categories including: (i) crops and varieties-related strategies, (ii) soil and water conservation strategies, (iii) change in agricultural system as strategy and (iv) others. 
Table 3 Adoption of on-farm climate change adaptation strategies (\%)

\begin{tabular}{lclcl}
\hline Strategies & All & Women & Men & Diff \\
\hline Crop and varieties-related strategies & & & & \\
Use of improved and treated seed & 55.0 & 39.37 & 69.92 & $-0.31^{* * *}$ \\
Introduction of new crop & 45.0 & 38.58 & 51.13 & $-0.13^{* *}$ \\
Use of high yield variety/hybrid & 29.6 & 20.47 & 38.35 & $-0.18^{* * *}$ \\
Use of drought-tolerant variety & 23.46 & 33.08 & 13.39 & $-0.20^{* * *}$ \\
Use of pest/disease-resistant & 11.15 & 7.9 & 15.04 & $-0.08^{* *}$ \\
Soil and water conservation technics & & & & \\
Use of organic manure & 67.69 & 50.39 & 84.21 & $-0.34 * * *$ \\
Contour farming & 64.23 & 48.03 & 79.69 & $-0.32^{* * *}$ \\
Tree planting & 13.08 & 7.87 & 18.04 & $-0.10^{* * *}$ \\
Hedge & 3.85 & 1.57 & 6.02 & $-0.04 * *$ \\
Strip & 3.46 & 4.72 & 2.25 & 0.02 \\
Cover crop & 2.69 & 1.5 & 3.75 & -0.02 \\
Mulching & 1.54 & 1.57 & 1.50 & 0.00 \\
Stone barriers & 0.77 & 0.00 & 1.5 & -0.02 \\
Changes in agriculture system & & & & \\
Crop association & 96.92 & 97.64 & 96.24 & 0.01 \\
Crop rotation & 70.38 & 52.76 & 87.21 & $-0.34^{* * *}$ \\
Monoculture & 31.54 & 21.84 & 47.73 & $0.16^{* * *}$ \\
Other strategies & & & & \\
Early sowing/planting & 63.46 & 66.14 & 60.90 & 0.05 \\
Agriculture mechanization & 57.69 & 55.12 & 60.15 & -0.05 \\
Late sowing/planting & 52.69 & 58.27 & 47.37 & $0.11 * * *$ \\
Increase use of pesticide & 29.62 & 17.32 & 41.35 & $-0.24 * * *$ \\
Integrated pest management & 0.38 & 5.51 & 12.03 & $-0.07^{* *}$ \\
Increase use of herbicide & 0 & 0.75 & -0.01 \\
\hline
\end{tabular}

*Significant at $10 \%$; * significant at $5 \%$; ***significant at $1 \%$

For crops and varieties-related strategies, the use of improved and treated seed and the introduction of new crop were found to be the most adopted adaptation strategies used by farmers in the study area (Table 3). This is in the same line with Touré et al. (2016) finding which cited use of improve crop varieties such as drought or pest tolerant crop as the most commonly adopted strategies in Cinzana area. A proportion test revealed significant $(P<0.01)$ differences between the percentage of women and men adopting improved/ treated seed and new crop.

The most adopted strategies related to soil and water conservation techniques were the use of organic manure and contour farming which were adopted by $67.7 \%$ and $64.2 \%$ of farmers, respectively, with significant $(p \leq 0.05)$ differences between men and women.

The study showed farmers also make changes in their production systems to adapt to climate change and variability. Some of these include mixed cropping (crop associations), crop rotation and monoculture systems. However, unlike crop rotation and monoculture, there was no significant differences between women and men.

The most adopted technologies among the other categories are the early sowing $(63.5 \%)$, late sowing $(52.7 \%)$ and agriculture mechanization $(57.7 \%)$. Women and men farmers are 
equally sowing early and use machine on their farm. Moreover, there was a significant difference between men and women on the rate of adoption of late sowing. Women farmers (58.2\%) adopted late sowing more than men (47.4\%).

A baseline study conducted in the study area by CCAFS in 2011 (Ouédraogo et al. 2017 ) indicated $40 \%, 55 \% 9 \%, 8 \%, 1 \%$ and $1 \%$ adoption of new crop introduction, use of organic manure, introduction of intercropping and crop rotation, use of pesticide, later and early planting and mechanization, respectively. Comparing to this study results, the level of these technologies adoption has increased by, respectively, 5\%, 12\%, and 80\%, 60\%, 62\%, $52 \%$ and $50 \%$, respectively. This could be explained by a series of climate-smart interventions activities implemented in the climate-smart villages of Cinzana by CCAFS program since 2011 .

All the above technologies are more adopted by men than women at the exception of late sowing. It exists different explanation to this fact. Nevertheless, the general explanation is attributing to gender consideration. Indeed, for most of the technologies women community management roles and traditions prevent them from the appropriate use of them. For instance, the difference between women and men adoption rate of introduction of new crop can be explained by the fact that women farmers are not allowed to grow most of the new crops introduced such as watermelon, fonio, Bambara nut and at some places, rice, etc. The fact that this technology is generally introduced by extension officer who, interact more with men than women can also explain the higher adoption of the technology by men as compared to women. It is usually NGOs which demand specifically to work equally with both men and women thus giving women access to some of the technologies. The same reason is relevant for the use of high yielding varieties, the use of drought-tolerant varieties which have, respectively, been more adopted by men than women even if these technologies are not highly adopted.

Regarding, the use of organic manure, women explained, during the discussion group, that they were not allowed to use animal manure even if they are the owners of the animals. This is reserved for family men only. Most of the women using this technology are widows.

The contour farming requires knowledge about the practice which one cannot have without training, most of the time women do not attend training and lack labor. The statistical proportion difference test between the two study groups concerning this strategy is significant. This is explained by the fact that agricultural extension and NGO, traditionally focused on improving production of cash crops (which in generally are not grown by women) by providing men with training, information and access to inputs and services.

Regarding crop rotation, women do not possess a large size of plot as; almost $75 \%$ of women have less than 2 hectares against about $80 \%$ of men who owned more than 10 hectares (MA 2016). Women do not own enough space to rotate crop that is also the reason for their high level of crop association adoption.

Late sowing is the only practice that has been more adopted by women than men. According to women during the discussion group, they must prioritize men farms against their own farm. Therefore, they whether sow early or late in order to be available when men need them on their farm.

\subsection{Farmers' level of adoption}

Figure 1 presents the adoption levels of farmers with significant differences between men and women $(p \leq 0.05)$ in the study area. About $62 \%$ of the sample was medium adopters (66.9\% of women and $56.4 \%$ of men). More women farmers were low adopters $(18.1 \%)$ 


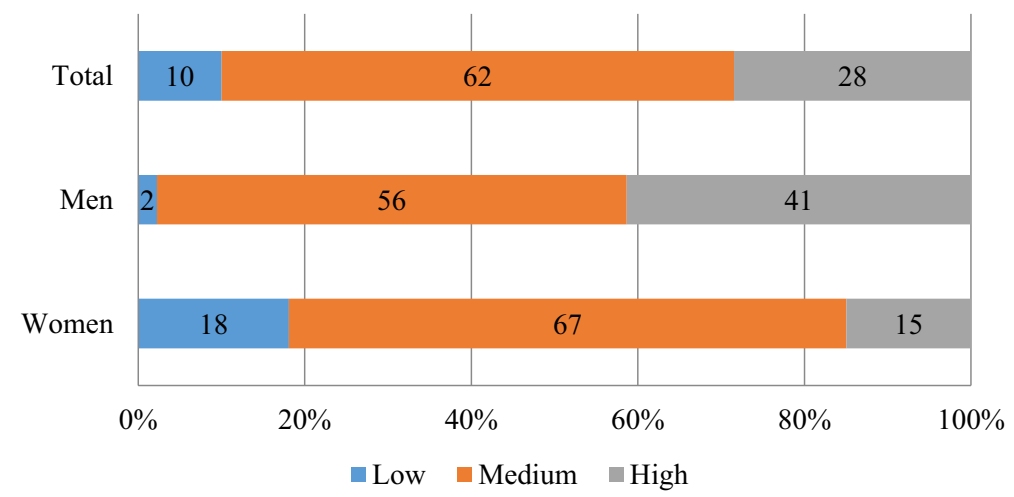

Fig. 1 Farmers' level of adoption (\%)

compared to men (2.3\%). And more men are high adopters (41.4\%) as compare to women $(15 \%)$. Even thus men and women have the same perception and adaptation strategies to climate change, they have different adoption level of adaptation strategies to climate change. This seek for the deep analysis of the determinants of farmers adoption level of adaptation strategies which will be developed in the next section.

\subsection{Determinants of farmers' adapted level of adaptation to climate change}

Table 4 presents the results of the multinomial logit regression analysis. The chi-square result showed that the likelihood ratio statistics is highly significant $(P=0.0000)$. This confirmed the fact that the model as a whole is statistically significant. The result indicated that sex, age of respondents, the number of free available labor and being the head of household have significant positive effects on adaptation strategy level.

The sex of the respondent had a significant $(p \leq 0.05)$ effect on the probability of being part of the medium and the high adopters as compared to the low level. It was evident that being a male farmer increases one's probability of being part of the medium and high adopters by $1.7 \%$ and $13 \%$, respectively. It reduces by $11 \%$ the probability of being part of low adopters. That is confirmed by Tenge and Hella (2004), Touré et al. (2016), Twyman et al. (2014) who reported that the non-adoption of certain agricultural technologies by women was explained by their limited access to information, land and other important resources due to sociocultural norms. Women farmers' lack of knowledge, learning opportunities, economic and land resources and sometimes labor disadvantage them to be part of the high adopters. For instance, during the discussion groups, women farmers indicated that it is part of the culture to attribute small and less fertile plot to them.

Being an aged farmer increases by $0.2 \%$, the probability for a farmer to be part of the high adopter. In the same line being the head of the household increases the probability by $11 \%$ for a farmer to be part of high adopters. The availability of free labor in the family positively increases the probability of farmers by $2 \%$ to be part of the high adopters. These findings are in agreement with Touré et al. (2016) which determine gender, age and being the household head as the main socioeconomic factors that impacted on adaptation decisions. This is also in the same line with Deressa et al. (2009) which indicated Male-headed households to be $9 \%$ more likely to adopt adaptation technologies. These factors determine 
Table 4 Determinants of adaptation strategy level (from multinomial logit model)

\begin{tabular}{|c|c|c|c|c|c|c|}
\hline \multirow[b]{2}{*}{ Variables } & \multicolumn{2}{|l|}{ Low level } & \multicolumn{2}{|c|}{ Medium level } & \multicolumn{2}{|l|}{ High level } \\
\hline & coefficient & Marginal effect & coefficient & Marginal effect & coefficient & Marginal effect \\
\hline Sex & - & $-0.115^{*}$ & $\begin{array}{l}1.392 * \\
(0.833)\end{array}$ & $\begin{array}{l}0.017 * \\
(.0868)\end{array}$ & $\begin{array}{l}2.319 * \\
(0.907)\end{array}$ & $\begin{array}{l}0.132 * \\
(0.068)\end{array}$ \\
\hline Age & - & 0.000 & $\begin{array}{l}0.011 \\
(0.036)\end{array}$ & $\begin{array}{l}-0.001 \\
(0.002)\end{array}$ & $\begin{array}{l}0.069 * * \\
(.0406)\end{array}$ & $\begin{array}{l}0.002 * * \\
(0.002)\end{array}$ \\
\hline Head of household & - & 0.077 & $\begin{array}{l}0.879 \\
(0.638)\end{array}$ & $\begin{array}{l}-0.038 \\
(0.057)\end{array}$ & $\begin{array}{l}1.478 * \\
(0.694)\end{array}$ & $\begin{array}{l}0.115 * \\
(0.057)\end{array}$ \\
\hline $\begin{array}{l}\text { Number of work- } \\
\text { ing children }\end{array}$ & - & 0.014 & $\begin{array}{l}0.156 \\
(0.144)\end{array}$ & $\begin{array}{l}-0.013 \\
(0.012)\end{array}$ & $\begin{array}{l}0.319 * * \\
(0.158)\end{array}$ & $\begin{array}{l}0.028 * * \\
(0.012)\end{array}$ \\
\hline Literacy & - & 0.042 & $\begin{array}{l}-0.597 \\
(0.681)\end{array}$ & $\begin{array}{l}-0.058 \\
(0.069)\end{array}$ & $\begin{array}{l}-0.405 \\
(0.756)\end{array}$ & $\begin{array}{l}0.015 \\
(0.069)\end{array}$ \\
\hline $\begin{array}{l}\text { Literacy of house- } \\
\text { hold }\end{array}$ & - & -0.018 & $\begin{array}{l}0.254 \\
(0.168)\end{array}$ & $\begin{array}{l}0.023 \\
(0.011)\end{array}$ & $\begin{array}{l}0.234 \\
(0.177)\end{array}$ & $\begin{array}{l}-0.004 \\
(0.011)\end{array}$ \\
\hline $\begin{array}{l}\text { Access to exten- } \\
\text { sion }\end{array}$ & - & -0.021 & $\begin{array}{l}0.321 \\
(0.521)\end{array}$ & $\begin{array}{l}0.044 \\
(0.055)\end{array}$ & $\begin{array}{l}0.335 \\
(0.591)\end{array}$ & $\begin{array}{l}-0.022 \\
(0.055)\end{array}$ \\
\hline Plot size & - & -0.005 & $\begin{array}{l}0.065 \\
(0.094)\end{array}$ & $\begin{array}{l}-0.001 \\
(0.004)\end{array}$ & $\begin{array}{l}0.102 \\
(0.097)\end{array}$ & $\begin{array}{l}0.006 \\
(0.004)\end{array}$ \\
\hline Land tenure status & - & -0.025 & $\begin{array}{l}0.329 \\
(0.445)\end{array}$ & $\begin{array}{l}0.009 \\
(0.048)\end{array}$ & $\begin{array}{l}0.424 \\
(0.507)\end{array}$ & $\begin{array}{l}0.016 \\
(0.0488)\end{array}$ \\
\hline Cons & & - & $\begin{array}{l}-0.321 \\
(1.108)\end{array}$ & - & $\begin{array}{l}-3.836 \\
(1.312)\end{array}$ & - \\
\hline
\end{tabular}

LR $\operatorname{chi} 2(18)=69.53 ;$ prob $>\operatorname{chi} 2=0.0000$

Log likelihood $=-195.77388$; pseudo $R 2=0.1508$

Standard errors in parentheses; $* * * p<0.01, * * p<0.05, * p<0.1$

the control of resources by women limiting their capacity of to decide and/or to act vis-avis of climate change and variability.

\section{Conclusion and recommendations}

Farmers in Cinzana, men and women equally, have a clear perception of their environment changes. They are perceiving changes in their climate and environment without any distinction. They have noticed some disturbance in the rainy and the dry seasons characterized by a shift in the beginning and the end of both seasons, a shortening of the rainy season and a lengthening of the dry season. They have also noticed an increase in the temperature with an erratic cool days and night.

Even though, women and men farmers in Cinzana community have the same perception of climate variabilities and change, they do not have the same level of adoption of adaptation strategies. Men are dominantly adopting all ongoing strategies in the study area, while female farmers are facing challenges to access some of adaptation technologies. Women farmers in Cinzana account for the low adopter of adaptation strategies as compared to men.

Several factors contribute to explain the different level of adaptation to climate change of men and women. The study revealed that being a man, a head of household and having 
labor are the most factors that bring farmers to a high level of adoption of adaptation strategies. All these factors determine the access to and control of resources for cropping activities. Women farmers lack important resources such as access to extension and training, adequate land size, financial resources (to buy inputs or hire labor), etc. These differences between women and men level of adopting adaptation strategies highlighted by this study are mostly driven by the sociocultural norms and economic factors.

The study highlighted that women appear to have low adaptive capacity. Therefore, there is need to enhance women adaptive capacity by improving access to services (finance, land, capacity building) through various complimentary measures including policy interventions and engagement of women in projects development and implementation. Gender must be taken into account in all climate change studies in order to target the appropriate policy or intervention to the right group, since this study has clearly shown that women and men do not have an equal adaptive capacity. More specifically project should put emphasis on women access to capacity building opportunities (training), credit, inputs, and market. In addition, measures should be taken to break the sociocultural barriers of women access to resources such as hiring more female extension officers in Cinzana area. This will simplify women access to extension services.

Acknowledgement This work was implemented as part of the CGIAR Research Program on Climate Change, Agriculture and Food Security (CCAFS), led by the International Center for Tropical Agriculture (CIAT). We acknowledge the CGIAR Trust Fund, Australia (ACIAR), Ireland (Irish Aid), Netherlands (Ministry of Foreign Affairs), New Zealand, Switzerland (SDC), The UK Government (UK Aid), USA (USAID), The European Union (EU) for funding the program and the International Fund for Agricultural Development (IFAD) for its technical support to CCAFS. Authors also gratefully acknowledge the financial support to the work from the Borlaug Higher Education for Agricultural Research and Development (BHEARD).

Open Access This article is licensed under a Creative Commons Attribution 4.0 International License, which permits use, sharing, adaptation, distribution and reproduction in any medium or format, as long as you give appropriate credit to the original author(s) and the source, provide a link to the Creative Commons licence, and indicate if changes were made. The images or other third party material in this article are included in the article's Creative Commons licence, unless indicated otherwise in a credit line to the material. If material is not included in the article's Creative Commons licence and your intended use is not permitted by statutory regulation or exceeds the permitted use, you will need to obtain permission directly from the copyright holder. To view a copy of this licence, visit http://creativecommons.org/licenses/by/4.0/.

\section{References}

Alle, C. S., \& UY, Vissoh V.P., Guibert H; Agbossou K.E., Gozé E; Afouda A.A, . (2013). Changements climatiques, perceptions et adaptations des producteurs sur le plateau d'allada au sud du bénin. European Journal of Scientific Research, 107, 530-545.

Aune, J. B. (2008). Adapting dryland agriculture in Mali to climate change. Journal of Norvegian University of Life Science. http://www.umb.no/statisk/noragric/publications/reports_other/aune_2008_mali.pdf.

Aymone, G.G. (2009) Understanding farmers' perceptions and adaptation to climate change and variability: The case of the Limpopo basin, South Africa. IFPRI Discussion paper 00849, International Food Policy Research Institute: Washington, DC.

Barnett, J., Lambert, S., \& Fry, I. (2008a). The hazards of indicators: Insights from the environmental vulnerability index. Annals of the Association of American Geographers, 98(1), 102-119. https://doi. org/10.1080/00045600701734315.

Barnett, J. B., Barrett, B. C., Jerry, R., \& Skees, R. J. (2008b). Poverty traps and index-based risk transfer products. World Development, 36(10), 1766-1785. 
Barrett, B. C. (2010). Measuring food insecurity. Science, 327(5967), 825-828. https://doi.org/10.1126/ science. 1182768 .

Bradshaw, B., Dolan, H., \& Smith, B. (2004). Farm-level adaptation to climatic variability and change: Crop diversification in the canadian prairies. Climatic Change, 6(7), 119-141.

Bravo-Baumann, H. (2000). Gender and livestock. Swiss Development Cooperation, Bern: Capitalization of Experiences on Livestock Projects and Gender. Working document.

Bridgeman, B., \& Tseng, P. (2011). Embodied cognition and the perception-action link. Phys. Life Rev., $8(1), 73-85$.

Bryant, C. R., Smit, B., Brklacich, M., Johnston, T., Smithers, J., Chiotti, Q., \& Singh, B. (2000). Adaptation in Canadian agriculture to climatic variability and change. In: S. M. Kane, \& G. W. Yohe (Eds.), Societal Adaptation to Climate Variability and Change (pp. 181-201). Dordrecht: Springer.https://doi. org/10.1007/978-94-017-3010-5_10.

Butt, T. A., McCall, B. A., Angerer, J., Dyke, P. T., \& Stuth, J. W. (2005. The economic and food security implications of climate change in Mali. Climatic Change, 68, 355-378. https://doi.org/10.1007/s1058 4-005-6014-0.

CCAFS (Climate Change Agriculture and Food Security) (2011). CCAFS Baseline Survey Indicators for Segou/Cinzana, Mali. CGIAR Research Program on Climate Change, Agriculture and Food Security (CCAFS). Copenhagen, Denmark. Available online at: www.ccafs.cgiar.org

Davis, M., Oswald, K., \& Mitchell, T. (2009). Climate change adaptation, disaster risk reduction and social protection. Change, 2(November), 201-217. https://doi.org/10.1111/j.2040-0209.2009.00320 2.x.

Deressa, T. T., Hassan, R. M., Ringler, C., Alemu, T., \& Yesuf, M. (2009). Determinants of farmers' choice of adaptation methods to climate change in the Nile Basin of Ethiopia. Global Environmental Change, 19(2), 248-255.

Diiro, G., Petri, M., Zemadim, B., Sinare, B., Dicko, M., Traore, D. and Tabo, R. (2016). Gendered analysis of stakeholder perceptions of climate change, and the barriers to its adaptation in mopti region in Mali. Research report no. 68. Patancheru 502 324. Telangana, India: International Crops Research Institute for the Semi-Arid Tropics. $52 \mathrm{pp}$.

Doss, C. (2014). Data needs for gender analysis in agriculture. In: Quisumbing A., Meinzen-Dick R., Raney T., Croppenstedt A., Behrman J., Peterman A.(Eds.), International Food Policy Research Institute (pp. 55-68). Dordrecht: Springer. https://doi.org/10.1007/978-94-017-8616-4_3.

Doss, C., Truong, M., Nabanoga, G., and Namaalwa, J. (2011) Women, marriage, and asset inheritance in Uganda. Working Paper 184. Manchester, UK: Chronic Poverty Research Center.

Doss, C., Kim, S. M., Njuki, J., Hillenbrand, E., and Miruka, M. (2014). Women's individual and joint property ownership: Effects on household decision-making. IFPRI Discussion Paper 1347. Washington, D.C.: International Food Policy Research Institute (IFPRI). http://ebrary.ifpri.org/cdm/ref/ collection/p15738coll2/id/128149.

FAO. (2011). Women in Agriculture: Closing the gender gap for development, The state of food and agriculture 2010-2011. Rome, Italy: FAO.

Greene, W. H. (1998). LIMDEP: A user's manual econometric software. Plainview, New York: Inc.

Haile, M. (2005). Weather patterns, food security and humanitarian response in sub-Saharan Africa. Philosophical Transactions of the Royal Society B: Biological Sciences, 2005(360), 2169-2182. https://doi.org/10.1098/rstb.2005.1746.

Hassan, R., \& Nhemachena, C. (2008). Determinants of African farmers' strategies for adapting to climate change: Multinomia choice analysis. African Journal of Agricultural and Resource Economics, $2,1$.

Hausman, J., \& McFadden, D. (1984). Specification tests for the multinomial logit model. Econometrica, 52(5), 1219-1240.

IPCC (2014) Climate Change 2014: Impacts, adaptation, and vulnerability. Part A: Global and sectoral aspects. Contribution of working group II to the fifth assessment report of the intergovernmental panel on climate change . In: Field, C.B., V.R. Barros, D.J. Dokken, K.J. Mach, M.D. Mastrandrea, T.E. Bilir, M. Chatterjee, K.L. Ebi, Y.O. Estrada, R.C. Genova, B. Girma, E.S. Kissel, A.N. Levy, S. MacCracken, P.R. Mastrandrea, and L.L. White (eds.). Cambridge University Press: Cambridge, pp. 1132.

IPCC (2018) Summary for Policymakers. In: Global warming of $1.5^{\circ} \mathrm{C}$. An IPCC Special Report on the impacts of global warming of $1.5^{\circ} \mathrm{C}$ above pre-industrial levels and related global greenhouse gas emission pathways, in the context of strengthening the global response to the threat of climate change, sustainable development, and efforts to eradicate poverty [V. Masson-Delmotte, P. Zhai, H. O. Pörtner, D. Roberts, J. Skea, P. R. Shukla,A. Pirani, W. Moufouma-Okia, C. Péan, R. Pidcock, S. Connors, J. B. R. Matthews, Y. Chen, X. Zhou, M. I. Gomis,E. Lonnoy, T. Maycock, M. Tignor, T. Waterfield (eds.)]. World Meteorological Organization, Geneva, Switzerland, pp. 32 
Jalloh, A., Nelson, G. C., Thomas, T. S., Zougmoré, R., \& Roy-Macauley, H. (2013). West African agriculture and climate change: A comprehensive analysis. IFPRI Research Monograph: Washington, D.C. International Food Policy Research Institute. https://doi.org/10.2499/9780896292048.

Jost, C., Kyazze, F., Naab, J., Neelormi, S., Kinyangi, J., Zougmore, R., \& Kristjanson, P. (2015). Understanding gender dimensions of agriculture and climate change in smallholder farming communities. Climate and Development, 5529(October), 1-12. https://doi.org/10.1080/17565529.2015.1050978.

Kakota, T., Nyariki, D., Mkwambisi, D., \& Kogi-Makau, W. (2011). Gender vulnerability to climate variability and household food insecurity. Climate and Development, 3(4), 298-309.

MA. (2016). Annuaire statistique 2015 du secteur développement rural, MA, 133p. Bamako Mali. http:// congo.countrystat.org/fileadmin/user_upload/countrystat_fenix/congo/docs/Annuaire\%20Statisti que $\% 20$ SDR $\% 202015 \% 20$.pdf.

Maddison, D. (2006) The perception of and adaptation to climate change in Africa. CEEPA discussion paper 10. Special Series on Climate Change and Agriculture in Africa.

Mitter, H., Techen, K. A., Sinabell, F., Helming, K., Kok, K., Jörg, A., Schmid, E., Bodirsky, L. B., Holman, I, Lehtonen, H., Leip, A., Mouël, L. C., Mathijs, E., Mehdi B., Michetti, M., Mittenzwei, K., Mora, O., Øygarden, L., Reidsma, P., Schaldach, R., Schönhart, M. (2019). A protocol to develop Shared Socio-economic Pathways for European agriculture. Journal of Environmental Management. https:// doi.org/10.1016/j.jenvman.2019.109701.

Müller, C., Cramer, W., Hare, L. W., \& Lotze-Campen, H. (2011). Climate change risks for African agriculture. Proceedings of the National academy of Sciences of the United States of America, 108(11), 4313-4315. https://doi.org/10.1073/pnas.1015078108.

Nelson, V., \& Stathers, T. (2009). Resilience, power, culture, and climate: a case study from semiarid Tanzania, and new research directions. Gender \& Development, 17(1), 81-94. https://doi. org/10.1080/13552070802696946.

Norris, E., \& Batie, S. (1987). Virginia farmers soil conservation decisions: An application of tobit analysis. Southern Journal of Agricultural Economics, 19(1), 89-97.

Ofuoku, A. U. (2011). Rural farmers' perception of climate change in central agricultural zone of delta state Nigeria. Indonesian Journal of Agricultural Science, 12(2), 63-69. https://doi.org/10.21082/ijas.v12n2 .2011 .

Ouédraogo, M., Dembélé, Y., \& Somé, L. (2010). Perceptions et stratégies d'adaptation aux changements des précipitations : Cas des paysans du Burkina Faso Sécheresse. Science et changements planétaires/ Sécheresse, 21(2), 87-96.

Ouédraogo, M., Zougmoré, R., Moussa, S. A., Partey, T. S., Thornton, K. P., Kristjanson, P., et al. (2017). Markets and climate are driving rapid change in farming practices in Savannah West Africa. Regional Environmental Change, 2017(17), 437-449. https://doi.org/10.1007/s10113-016-1029-9.

Partey, S. T., Dakorah, A. D., Zougmoré, R. B., Ouédraogo, M., Nyasimi, M., Nikoi, G. K., \& Huyer, S. (2018). Gender and climate risk management: evidence of climate information use in Ghana. Climatic Change, 158, 61-75. https://doi.org/10.1007/s10584-018-2239-6.

Peterman, A., Behrman, J. and Quisumbing, A. (2010). A review of empirical evidence on gender differences in non-land agricultural inputs, technology, and services in developing countries. ESA Working Paper No. 11-11, FAO. http://www.fao.org/3/a-am316e.pdf.

Sanogo, K., Binam, J., Bayala, J., Villamor, B. G., Kalinganire, A., \& Dodiomon, S. (2016). Farmers' perceptions of climate change impacts on ecosystem services delivery of parklands in southern Mali. Agroforestry Systems, 91(2), 345-361.

Swai, O. W., Mbwambo, J. S., \& Magayane, F. T. (2012). Gender and perception on climate change in Bahi and Kondoa Districts, Dodoma Region, Tanzania Swai, Department. Journal of African Studies and Development, 4(9), 218-231. https://doi.org/10.5897/JASD12.038.

Tenge, J. D., \& Hella, P. J. (2004). Social and economic factors affecting the adoption of soil and water conservation in West Usambara Highlands Tanzania. Land Degradation and Development, 15(2), 99-114.

Touré, H., Zampaligre, N. K. T., \& Kyei-Baffour, N. (2016). Farmers' perceptions of climate variability and change and adaptation strategies in Cinzana Mali. Journal of Agricultural Studies, 4(3), 13. https://doi. org/10.5296/jas.v4i3.9331.

Traore, B., Descheemaeker, K., Van Wijk, M. T., Corbeels, M., Supit, I., \& Giller, K. E. (2017a). Modelling cereal crops to assess future climate risk for family food self-sufficiency in southern Mali. Field Crops Research, 201, 133-145.

Traore, K., Sidibe, D. K., Coulibaly, H., \& Bayala, J. (2017b). Optimizing yield of improved varieties of millet and sorghum under highly variable rainfall conditions using contour ridges in Cinzana Mali. Agriculture \& Food Security, 20176, 11. https://doi.org/10.1186/s40066-016-0086-0.

Tse, K. Y. (1987). A diagnostic test for the multinomial logit model. Journal of Business and Economic Statistics, 5(2), 283-286. https://doi.org/10.1080/07350015.1987.10509587. 
Twyman, J., Green, M., Bernier, Q., Kristjanson, P., Russo, S., Tall, A., Ampaire, E., Nyasimi, M., Mango, J., McKune, S., Mwongera, C., and Ndourba, Y. (2014). Gender and climate change perceptions, adaptation strategies, and information needs preliminary results from four sites in Africa. CCAFS working paper no. 83. CGIAR Research Program on Climate Change, Agriculture and Food Security (CCAFS). Copenhagen, Denmark. Available online at: www.ccafs.cgiar.org.

UN. (2017). The Sustainable Development Goals report 2017 (64p.). New York: United Nations publication.

Wright, H. \& Chandani, A. (2014) Gender in scaling up commu- nity based adaptation to climate change. In: L. Schipper, J. Ayers, H. Reid, S. Huq, \& Rahman, A. (Eds.), Community based adaptation to climate change: Scaling it up. pp. 226-238.

Zougmoré, R. B., Partey, S. T., Ouédraogo, M., Torquebiau, E., \& Campbell, B. M. (2018). Facing climate variability in sub-Saharan Africa: Analysis of climate-smart agriculture opportunities to manage climate-related risks. Cahiers Agricultures, 27, 34001. https://doi.org/10.1051/cagri/2018019.

Publisher's Note Springer Nature remains neutral with regard to jurisdictional claims in published maps and institutional affiliations.

\section{Authors and Affiliations}

\section{Fatimata Bintou Diarra ${ }^{1,2} \cdot$ Mathieu Ouédraogo $^{1}$ (D) Robert B. Zougmoré ${ }^{1}$. Samuel Tetteh Partey ${ }^{1} \cdot$ Prosper Houessionon $^{1} \cdot$ Amos Mensah $^{2}$}

Fatimata Bintou Diarra

fatimatabintoudiarra@gmail.com

Robert B. Zougmoré

r.zougmore@cgiar.org

Samuel Tetteh Partey

stpartey@gmail.com

Prosper Houessionon

p.houessionon@cgiar.org

Amos Mensah

amensah@knust.edu.gh

1 The CGIAR Research Program on Climate Change, Agriculture and Food Security (CCAFS), International Crops Research Institute for the Semi-Arid Tropics (ICRISAT), BP 320, Bamako, Mali

2 Kwame Nkrumah University of Science and Technology (KNUST), Kumasi, Ghana 